https://helda.helsinki.fi

\title{
The Welfare Multiplier of Public Infrastructure Investment
}

\section{Ganelli, Giovanni}

2016

Ganelli , G \& Tervala , J V S 2016 , ' The Welfare Multiplier of Public Infrastructure Investment ' , IMF Working Papers, no. 16/40 .

http://hdl.handle.net/10138/160878

Downloaded from Helda, University of Helsinki institutional repository.

This is an electronic reprint of the original article.

This reprint may differ from the original in pagination and typographic detail.

Please cite the original version. 


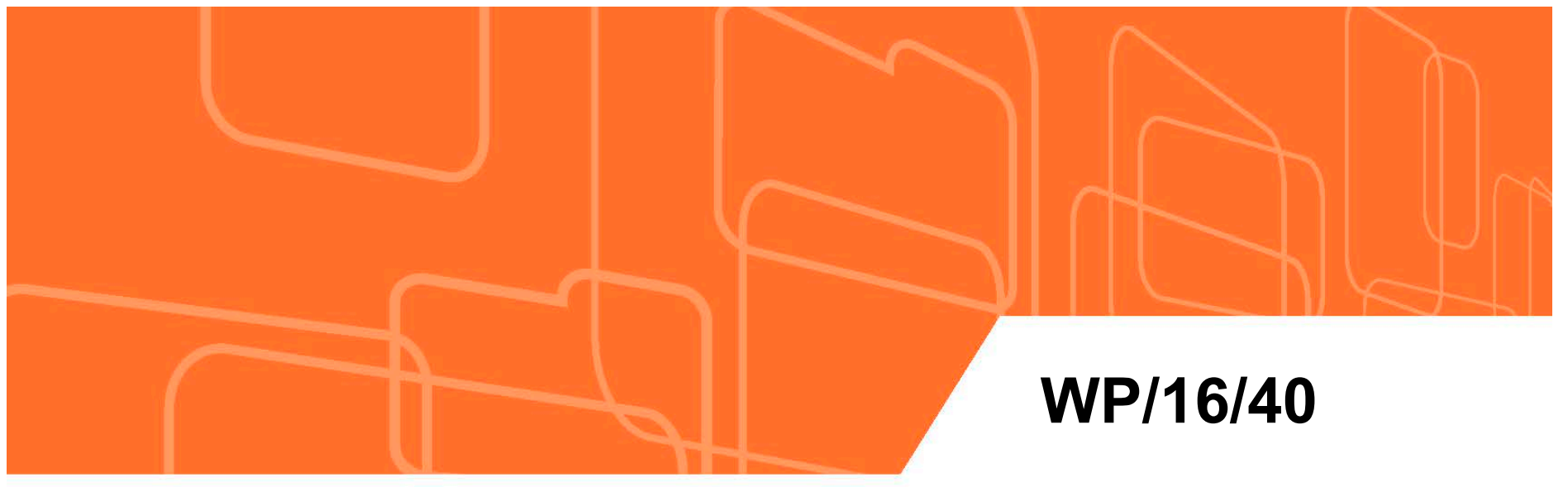

\section{IMF Working Paper}

\section{The Welfare Multiplier of Public Infrastructure Investment}

by Giovanni Ganelli and Juha Tervala 


\title{
IMF Working Paper
}

Regional Office for Asia and the Pacific

\section{The Welfare Multiplier of Public Infrastructure Investment Prepared by Giovanni Ganelli and Juha Tervala ${ }^{1}$}

Authorized for distribution by Odd Per Brekk

February 2015

IMF Working Papers describe research in progress by the author(s) and are published to elicit comments and to encourage debate. The views expressed in IMF Working Papers are those of the author(s) and do not necessarily represent the views of the IMF, its Executive Board, or IMF management.

\begin{abstract}
We analyze the welfare multipliers of public spending (the consumption equivalent change in welfare for one dollar change in public spending) in a DSGE model. The welfare multipliers of public infrastructure investment are positive if infrastructure is sufficiently effective. When the medium-term output multipliers are consistent with the empirical estimates (1-1.4), the welfare multiplier is 0.8 . That is, a dollar spent by the government for investment raises domestic welfare by equivalent of 0.8 dollars of private consumption. This suggests that the welfare gains of public infrastructure investment, if chosen wisely, may be substantial.
\end{abstract}

JEL Classification Numbers: E62, F41, H42, H54

Keywords: Public Infrastructure, Public Investment, Welfare

Author’s E-Mail Address:gganelli@imf.org, juha.tervala@helsinki.fi

\footnotetext{
${ }^{1}$ We are grateful for comment to Marlene Isore, Javier Kapsoli, Pau Rabanal, Antti Ripatti and Juuso Välimäki.
} 


\section{INTRODUCTION}

The case for a public investment push is gaining increasing consensus in the policy debate. The IMF (2014), for example, has argued that, given current low government borrowing costs, and concerns about the impact on both potential and near-term growth of infrastructure bottlenecks in several countries, this might be a good time for a public infrastructure push. Using both cross country panel estimates and model simulations, IMF (2014) concludes that increased public infrastructure investment raises output in both the short and long term, particularly during periods of economic slack and monetary accommodation.

In Europe, the "Juncker" investment plan launched by the Commission and the European Investment Bank (EIB) aims at increasing public investment by at least 315 billion Euros in the medium term. In addition, individual countries, for example Germany, which has recently announced a boost to investment spending, are also budgeting to update their infrastructure. Similarly, in Japan, large part of fiscal stimulus under the so-called "second arrow" of Abenomics is earmarked to infrastructure projects.

Against this background, it is important for the economic profession to evaluate the economic impact of increasing public infrastructure. In the existing literature, this has been done primarily by focusing on the implications for output, i.e. by looking at the output multipliers of fiscal policy. The main contribution of this paper is to focus on welfare, by using a New Keynesian DSGE model to analyze the welfare multipliers of public investment. This is a relevant exercise because welfare and output do not necessarily move in the same direction in a general equilibrium setting. Despite this, while the welfare multipliers of public consumption spending have been analyzed before, our paper is, to the best of our knowledge, the first systematic attempt to study the welfare multipliers of public investment in a state-ofthe-art DSGE model.

Our focus on the welfare multiplier is inspired by Mankiw and Weinzierl (2011), who use a general equilibrium model to show that the commonly used "bang for the buck" calculations (by how much output increases for a dollar of public spending) are misleading in assessing the welfare effects of alternative fiscal policies, because they ignore the composition of GDP. Similarly, Sims and Wolff (2013), carry out a historical simulation for the US, which shows a strong negative correlation between the output and the welfare multiplier, concluding that the output multiplier is likely to be a poor measure of the welfare effects of a government

spending shock. Following Rendhal (2015) and Sims and Wolff (2013), we measure the welfare multiplier as the consumption equivalent change in welfare for one dollar change in government spending. 
Our main finding is that, in a benchmark parameterization of our model in which output multipliers are consistent with empirical estimates (as provided for example Gechert and Rannenberg's (2014) and IMF (2014)), the domestic welfare multiplier of public infrastructure investment is 0.8 , which implies that one dollar spent for public infrastructure investments raises domestic welfare by the equivalent of 0.8 dollars of private consumption. Our results therefore show that a public infrastructure push would not only, as already shown by previous studies, increase output, but would also have a positive effect on welfare.

The open economy framework enables the analysis of the international welfare effects of domestic government fiscal intervention. Ignoring positive spillovers would underestimate the total benefits of domestic public infrastructure investment for the world economy. In our model, an improvement in the foreign terms of trade causes a welfare improvement in the foreign economy. The positive welfare spillover implies that the world welfare multiplier of public investment is larger (0.9) than the domestic welfare multiplier (0.8).

The above result is not directly comparable to the existing literature in terms of its welfare implications, because our paper is the first one to study the welfare multiplier of public investment. One important observation, however, is that our analysis lends more support to those who favor an increase in infrastructure spending, compared for example to Mankiw and Weinzierl (2011), who argue that public investment is an ineffective stabilization tool from the welfare point of view, because it unambiguously crowds out private investment in their model. In our model, public investment does not crowd out private investment, consistently with the empirical evidence presented in IMF (2014). This can contribute to explain the large welfare gains that we derive from this kind of fiscal policy shock.

Bom and Ligthart (2014) study the welfare effects of public infrastructure investment in a small-open economy. They find that that a permanent increase in public investment raises welfare in the long term if the output elasticity of public capital exceeds the public investment-to-GDP ratio which averages 3 percent in OECD countries. In line with the findings of Bom and Ligthart (2014), we find that the welfare multipliers of public infrastructure investment are sensitive to the output elasticity of public infrastructure. We find that the welfare multiplier is virtually zero when the output elasticity of public infrastructure is three percent. The welfare multiplier of public investment critically depends on its productivity and therefore ensuring a high productivity of investment is the key to fully reaping the benefits of an infrastructure spending push. IMF (2015) argues that governments should strengthen institutions that are responsible for the planning, allocation, and implementation of public investments to enhance the productivity of public investment. Good public investment management would secure a positive welfare multiplier of public investment. 
Another important result is that the welfare multiplier of public consumption spending is negative at -0.3 percent in the benchmark version of the model. This result is consistent with Rendhal (2015), who shows that, if the duration of the fiscal expansion is $0-20 \%$ that of the crisis that drives the economy into a liquidity trap, the welfare multiplier of public consumption is in the -0.4 to -0.2 percent range. Furthermore, in our model the welfare multiplier of public consumption is negative when public spending yields low utility relative to private utility. This is consistent with Sims and Wolff (2013), who show that the sign of the welfare multiplier of public consumption is negative when steady state government spending is set higher than its welfare maximizing level.

The policy implication of our analysis is that public infrastructure investment may be the best way to stimulate the economy not only from the output point of view, but also from the point of view of welfare. A public infrastructure push is desirable, because it has, if infrastructure is sufficiently effective, a positive welfare multiplier.

The rest of the paper is organized as follows: Section 2 introduces the model. Section 3 discusses the parameterization. Section 4 analyzes the output and welfare multipliers of fiscal expansion. Section 5 concludes the paper.

\section{MODEL}

We use a standard New Keynesian set up. There are two countries in the world, which we label home and foreign. The world population is normalized to one, and there is a continuum of firms and households indexed by $z \in[0,1]$. A fraction $n(1-n)$ of households and firms are domestic (foreign). Within this framework, we look at two kind of public spending: consumption and infrastructure investment.

\section{A. Demand Side: Households}

All households have identical preferences. The utility function of the representative domestic household is given by

$U_{t}=\sum_{s=t}^{\infty} \beta^{s-t}\left[\log C_{s}-\frac{\left(l_{s}(z)\right)^{1+1 / v}}{1+1 / v}+v \log G_{s}^{C}\right]$

where $0<\beta<1$ is the discount factor, $C_{t}$ is a private consumption index, $G_{t}^{C}$ is public consumption and $\iota$ is the weight of public consumption relative to private consumption. We assume endogenous labor supply, where $l_{t}(z)$ is the household's labor supply, $v$ is the Frisch elasticity of labor supply. 
The private consumption index is defined as

$C_{t}=\left[n \alpha^{\frac{1}{\rho}}\left(C_{t}^{h}\right)^{\frac{\rho-1}{\rho}}+(1-n \alpha)^{\frac{1}{\rho}}\left(C_{t}^{f}\right)^{\frac{\rho-1}{\rho}}\right]^{\frac{\rho}{\rho-1}}$

where $C_{t}^{h}\left(C_{t}^{f}\right)$ is an index of domestic (foreign) goods and $\rho>0$ is the elasticity of substitution between domestic and foreign goods (cross-country substitutability). In this setup, $n \alpha(0<n \alpha<1)$ is the share of domestic goods in the consumption basket, and the parameter $\alpha>1$ captures the degree of home bias in consumption.

The government consumption indexes are identical to the private consumption ones. In addition, an analogous index governs public infrastructure spending.

The consumption of domestic and foreign goods $C_{t}^{h}$ and $C_{t}^{f}$ are aggregates defined as follows

$C_{t}^{h}=\left[n^{-\frac{1}{\theta}} \int_{0}^{n}\left(c_{t}^{h}(z)\right)^{\frac{\theta-1}{\theta}} d z\right]^{\frac{\theta}{\theta-1}}, \quad C_{t}^{f}=\left[(1-n)^{-\frac{1}{\theta}} \int_{n}^{1}\left(c_{t}^{f}(z)\right)^{\frac{\theta-1}{\theta}} d z\right]^{\frac{\theta}{\theta-1}}$,

where $c_{t}^{h}(z)\left(c_{t}^{f}(z)\right)$ is the consumption of differentiated domestic (foreign) good $z$ by the representative domestic household, and $\theta>1$ is the elasticity of substitution between two goods produced in the same country (within-country substitutability).

The foreign private consumption index is

$C_{t}^{*}=\left[n \alpha^{* \frac{1}{\rho}}\left(C_{t}^{* h}\right)^{\frac{\rho-1}{\rho}}+\left(1-n \alpha^{*}\right)^{\frac{1}{\rho}}\left(C_{t}^{* f}\right)^{\frac{\rho-1}{\rho}}\right]^{\frac{\rho}{\rho-1}}$,

where asterisks indicate consumption by the representative foreign household, and $n \alpha^{*}$ $\left(0<n \alpha^{*}<1\right)$ is the share of domestic goods in the foreign consumption basket. We assume home bias in consumption, requiring $\alpha^{*}<1$.

Given the consumption indexes, the private demand functions for the differentiated domestic and foreign goods by domestic and foreign households are, with obvious notation 


$$
\begin{aligned}
& c_{t}^{h}(z)=\left[\frac{p_{t}^{h}(z)}{P_{t}^{h}}\right]^{-\theta}\left[\frac{P_{t}^{h}}{P_{t}}\right]^{-\rho} \alpha C_{t}, c_{t}^{f}(z)=\left[\frac{\left(p_{t}^{f}(z)\right.}{P_{t}^{f}}\right]^{-\theta}\left[\frac{P_{t}^{f}}{P_{t}}\right]^{-\rho}\left(\frac{1-n \alpha}{1-n}\right) C_{t} \\
& c_{t}^{* h}(z)=\left[\frac{\left(p_{t}^{* h}(z)\right.}{P_{t}^{* h}}\right]^{-\theta}\left[\frac{P_{t}^{* h}}{P_{t}^{*}}\right]^{-\rho} \alpha^{*} C_{t}^{*}, c_{t}^{* f}(z)=\left[\frac{p_{t}^{* f}(z)}{P_{t}^{* f}}\right]^{-\theta}\left[\frac{P_{t}^{* f}}{P_{t}^{*}}\right]^{-\rho}\left(\frac{1-n \alpha^{*}}{1-n}\right) C_{t}^{*} .
\end{aligned}
$$

Demand functions for the consumption goods by the domestic and foreign governments are defined in an analogous way.

In the above demand functions, $p_{t}^{h}(z)$ and $p_{t}^{f}(z)$ denote the domestic currency price of domestic and foreign goods, respectively, while $P_{t}^{h}$ and $P_{t}^{f}$ are the price indexes that correspond to domestic and foreign aggregate consumption baskets $C_{t}^{h}$ and $C_{t}^{f}$. Price indexes are expressed in terms of the local currency, and corresponding foreign currency price indexes are denoted by an asterisk: e.g. $p_{t}{ }^{* h}(z)$ is the foreign currency price of a differentiated domestic brand. $P_{t}^{h}$ and $P_{t}^{f}$ are defined as

$$
\begin{aligned}
& P_{t}^{h}=\left[n^{-1} \int_{0}^{n}\left(p_{t}^{h}(z)\right)^{1-\theta} d z\right]^{\frac{1}{1-\theta}}, \\
& P_{t}^{f}=\left[(1-n)^{-1} \int_{n}^{1}\left(p_{t}^{f}(z)\right)^{1-\theta} d z\right]^{\frac{1}{1-\theta}} .
\end{aligned}
$$

And the overall domestic price index is

$$
P_{t}=\left[n \alpha\left(P_{t}^{h}\right)^{1-\rho}+(1-n \alpha)\left(P_{t}^{f}(\tau)\right)^{1-\rho}\right]^{\frac{1}{1-\rho}}
$$

The corresponding foreign indexes are defined in an analogous way.

The budget constraint of the domestic household is given by

$$
D_{t}=\left(1+i_{t}\right) D_{t-1}+w_{t} l_{t}(z)-P_{t} C_{t}+\pi_{t}-P_{t} T_{t}
$$

where $D_{t}$ denotes holding of domestic nominal bonds (denominated in domestic currency), $i_{t}$ the nominal interest rate on bonds between $\mathrm{t}-1$ and $\mathrm{t}, w_{t}$ the nominal wage, $\pi_{t}$ nominal dividends (profits) of domestic firms, and $T_{t}$ lump-sum taxes. The domestic bond is the only internally traded asset and a global asset-market clearing condition holds for domestic bonds: $n D_{t}+(1-n) D_{t}^{*}=0$. 
The foreign economy is similar to the domestic one, except for the fact that the foreign bond $\left(\mathrm{F}^{*}\right)$, denominated in the foreign currency, is not traded internationally. The net supply of foreign bonds is zero, because the foreign country has only one representative household. The budget constraint of the foreign household is

$$
\frac{D_{t}^{*}}{S_{t}}+F_{t}^{*}=\left(1+i_{t}\right) \frac{D_{t-1}^{*}}{S_{t}}+\left(1+i_{t}^{*}\right) F_{t-1}^{*}+w_{t}^{*} l_{t}^{*}(z)-P_{t}^{*} C_{t}^{*}+\pi_{t}^{*}+P_{t}^{*} T_{t}^{*}
$$

where $S_{t}$ is the nominal exchange rate, defined as the price of the foreign currency expressed in the domestic currency, so that an increase in it is an exchange rate depreciation for the domestic currency.

In order to ensure stationarity of the model, we follow Schmitt-Grohe and Uribe (2003) and assume that the domestic interest rate is increasing in the level of net foreign debt. This is done by including a risk premium that forces external debt in the long term to return to the initial (zero) level. The interest parity condition with risk premium is given by

$$
\left(1+i_{t}\right)=\left(1+i_{t}^{*}\right) \frac{S_{t+1}}{S_{t}}+\psi\left(\exp \left(D_{t}\right)-1\right)
$$

where $\psi\left(\exp \left(D_{t}\right)-1\right)$ is the risk premium.

The representative domestic household's optimality conditions are

$$
\begin{aligned}
& 1=\beta\left(1+i_{t}\right) \frac{P_{t} C_{t}}{P_{t} C_{t+1}}, \\
& l_{t}(z)=\left(\frac{w_{t}}{C_{t} P_{t}}\right)^{v} .
\end{aligned}
$$

Equation (3) is the Euler equation of consumption, which implies that the representative household smooths consumption. Equation (4) governs the optimal labor supply. The labor supply is an increasing function of the real wage and a decreasing function of private consumption.

\section{B. Monetary and Fiscal Policy}

The government budget constraint in per-capita terms can be expressed as

$$
P_{t} T_{t}=G_{t}^{I}+G_{t}^{C},
$$


where $T$ denotes lump-sum taxes and $G^{I}$ spending for public investment in infrastructure. For simplicity, taxes are non-distortionary. If an increase in public spending was financed with distortionary taxes, the expansionary effect of fiscal policy would be smaller. Consequently, the welfare multiplier of public investment might be somewhat smaller.

Both types of public spending follow an AR (1) process

$\hat{G}_{t}^{i}=\rho^{i} \hat{G}_{t-1}^{i}+\varepsilon_{t}^{i}$,

where $\mathrm{i}=\mathrm{I}, \mathrm{C}, \rho^{i} \in[0,1]$ and $\varepsilon_{t}^{i}$ is a zero mean white-noise process representing an unexpected change in public spending. Percentage changes from the initial steady state (denoted by the subscript zero) are denoted by hats (for example: $\left.\hat{x}_{t}=d x_{t} / x_{0}\right)^{2}$

The central bank adjust the nominal interest rate according to a log-linear Taylor rule with interest rate smoothing

$\hat{i_{t}}=\left(1-\mu_{1}\right) \mu_{2} \Delta P_{t}+\mu_{1} \hat{i}_{t-1}$,

where coefficients $\mu_{1}$ and $\mu_{2}$ are non-negative and $\Delta$ is the first difference operator. If the economy was at the zero lower bound, welfare multipliers could be somewhat different. However, Rendhal (2015) has already analyzed the welfare multiplier of public consumption in a liquidity trap. In addition, the effects of a public infrastructure investment shock in the current version of the model are very well in line with the empirical evidence.

\section{Supply Side: Firms}

As in Basu and Kollmann (2013), we assume the simplest version of the production function with public infrastructure. All firms produce differentiated goods with a production function

$y_{t}(z)=l_{t}(z)\left(K_{t}^{G}\right)^{\phi}$

where $y_{t}(z)$ is the output of the representative firm $z, l_{t}(z)$ is the labor input, $K_{t}^{G}$ is the stock of public infrastructure, and $\phi$ is the output elasticity of public infrastructure. We assume a positive $\phi$, which implies that the production function has increasing returns with

\footnotetext{
${ }^{2}$ Variables whose initial value is zero are normalized by private consumption
} 
respect to public infrastructure, as in Basu and Kollmann (2013), Bom and Ligthart (2014), Leduc and Wilson (2013) and Iwata (2013).

Omitting private capital from the production function is a shortcut to facilitate the model's solution. However, given the empirical result in IMF (2014), that public infrastructure investment does not crowd out private investment, this omission does not have significant implications for the main question in which we are interested in this paper, namely the welfare multiplier of an increase in public infrastructure.

The stock of public infrastructure evolves according to

$K_{t+1}^{G}=(1-\lambda) K_{t}^{G}+G_{t}^{I}$,

where $\lambda$ is the depreciation rate of public infrastructure.

The domestic firm maximizes its profits

$\pi_{t}(z)=p_{t}^{h}(z) y_{t}(z)-w_{t} l_{t}(z)$

taking into account the production function (6) and the demand for its goods

$y_{t}(z)=\left[\frac{p_{t}^{h}(z)}{P_{t}^{h}}\right]^{-\theta}\left[\frac{P_{t}^{h}}{P_{t}}\right]^{-\rho} n \alpha\left(C_{t}+G_{t}^{A}\right)+\left[\frac{p_{t}^{h}(z)}{S_{t} P_{t}^{* h}}\right]^{-\theta}\left[\frac{S_{t} P_{t}^{* h}}{S_{t} P_{t}^{*}}\right]^{-\rho}(1-n) \alpha^{*}\left(C_{t}^{*}+G_{t}^{* A}\right)$

where $G_{t}^{A}$ is aggregate public spending $\left(G_{t}^{A}=G_{t}^{I}+G_{t}^{C}\right)$. Using equations (6) and (8), domestic profits can be expressed as

$$
\begin{aligned}
& \pi_{t}(z)=\left[p_{t}^{h}(z)-\frac{w_{t}}{\left(K_{t}^{G}\right)^{\phi}}\right] \times \\
& \left\{\left[\frac{p_{t}^{h}(z)}{P_{t}^{h}}\right]^{-\theta}\left[\frac{P_{t}^{h}}{P_{t}}\right]^{-\rho} n \alpha\left(C_{t}+G_{t}^{A}\right)+\left[\frac{p_{t}^{h}(z)}{S_{t} P_{t}^{* h}}\right]^{-\theta}\left[\frac{S_{t} P_{t}^{* h}}{S_{t} P_{t}^{*}}\right]^{-\rho}(1-n) \alpha^{*}\left(C_{t}^{*}+G_{t}^{* A}\right)\right\}
\end{aligned}
$$

Under the flexible price solution of our model, the domestic firm would maximize equation (9) with respect to $p_{t}^{h}(z)$, implying

$$
p_{t}^{h}(z)=\frac{\theta}{\theta-1} \frac{w_{t}}{\left(K_{t}^{G}\right)^{\phi}}
$$


Equation (10) expresses the fact under flexible prices the price of the representative good is a constant mark-up, determined by within-country substitutability, over the marginal cost.

However, we introduce nominal rigidities following Calvo (1983), by assuming that each firm can reset its prices with a probability of $1-\gamma$ in any given period, independently of the time elapsed since the last adjustment and of other firms. Under this framework, the domestic firm seeks to maximize

$$
\max _{p_{t}^{h}(z)} V_{t}(z)=\sum_{s=t}^{\infty} \gamma^{s-t} \zeta_{t, s} \pi_{s}(z)
$$

where $\zeta_{t, s}$ is the stochastic discount factor between periods $\mathrm{t}$ and $\mathrm{s}$.

The result of the firm optimization problem under Calvo pricing yields

$p_{t}^{h}(z)=\left(\frac{\theta}{\theta-1}\right) \frac{\sum_{s=t}^{\infty} \gamma^{s-t} \zeta_{t, s} Q_{s} \frac{w_{s}}{\left(K_{s}^{G}\right)^{\phi}}}{\sum_{s=t}^{\infty} \gamma^{s-t} \zeta_{t, s} Q_{s}}$,

where $Q_{t}=\left[\frac{1}{P_{t}^{h}}\right]^{-\theta}\left[\frac{P_{t}^{h}}{P_{t}}\right]^{-\rho} n \alpha\left(C_{t}+G_{t}^{A}\right)+\left[\frac{1}{S_{t} P_{t}^{* h}}\right]^{-\theta}\left[\frac{S_{t} P_{t}^{* h}}{S_{t} P_{t}^{*}}\right]^{-\rho}(1-n) \alpha^{*}\left(C_{t}^{*}+G_{t}^{* A}\right)$.

A convenient and intuitive way of looking at the Calvo price solution is to log-linearize it as follows

$\hat{p}_{t}^{h}(z)=\beta \gamma \hat{p}_{t+1}^{h}(z)+(1-\beta \gamma)\left(\hat{w}_{t}-\phi \hat{K}_{t}^{G}\right)$.

The above expression makes it clear that the change in the optimal price is a weighted average of the changes in current and future marginal costs, and that an increase in the public infrastructure stock reduces the optimal price. 


\section{Consolidated Budget Constraint}

The consolidated budget constraint of the domestic economy can be derived by plugging equations (5) and (7) into equation (2), as follows ${ }^{3}$

$$
D_{t}-\left(1+i_{t}\right) D_{t-1}=p_{t}^{h}(z) y_{t}(z)-P_{t} C_{t}
$$

We define the current account trade balance as the change in net foreign assets (following Obstfeld and Rogoff 1995)

$$
C A_{t}=D_{t}-D_{t-1}=i_{t} D_{t-1}+p_{t}^{h}(z) y_{t}(z)-P_{t} C_{t} .
$$

The current account is the sum of the service account (interest income) and the trade balance account, defined as the difference between the value of domestic output and of consumption.

\section{E. Initial Steady State}

We log-linearize the model around a symmetric steady state where both initial net foreign assets and public spending are zero $\left(D_{0}=G_{0}^{I}=G_{0}^{C}=0\right)$. We also assume that the size of the public infrastructure stock in the initial steady state is normalized to one. We would like to emphasize the initial level of steady state infrastructure is not a key to our main results; the output elasticity of public infrastructure drives the results, regardless of the initial level of public infrastructure. Under these assumptions, the consolidated budget constraint of the domestic economy (11) implies $C_{0}=y_{0}$, and equations (4), (6) and (10) imply that the initial level of employment (and output) is

$l_{0}(z)=\left[\frac{(\theta-1)}{\theta}\right]^{\frac{1}{1+1 / v}}$

\section{Parameterization}

The two countries are assumed to be of equal size $(n=0.5)$. We set the discount factor $\beta$ to 0.995 , since we interpret our periods as quarters, this is equivalent to a $2 \%$ annual interest rate (as in Iwata (2013)).

\footnotetext{
${ }^{3}$ The consolidated budget constraint for the foreign economy, which takes into account the market-clearing condition for domestic bonds and that the net supply of the foreign bond is zero, is

$\frac{n}{1-n} \frac{D_{t}}{S_{t}}-\left(1+i_{t}\right) \frac{n}{1-n} \frac{D_{t-1}}{S_{t}}=p_{t}^{* f}(z) y_{t}^{*}(z)-P_{t}^{*} C_{t}^{*}$.
} 
In the literature within-country substitutability parameter $\theta$ is usually parameterized within the 5 to 21 range. We set at 11, based on Basu and Fernald (1997), implying a 10 percent markup over the marginal cost in the steady state. Cross-country substitutability is set at $\rho=1.5$, a commonly used value in the international macro models (see, for example, Dong (2012)). Based on existing macro evidence and surveys (e.g. Keane and Rogerson (2012) and Chetty et al. (2013)), the Frisch elasticity of labor supply $v$ is set at 0.7 .

The Calvo parameter $\gamma$ is set to 0.5 . This value is widely used in New Keynesian models and implies an average delay of two periods (six months) between price adjustments, consistently with the evidence presented by Bils and Klenow (2004) that prices tend to change twice a year.

We set the home bias parameter of the model in order to imply a realistic import-to-GDP. We set $\alpha$ to 1.68 and $\alpha^{*}=(1-n \alpha) / n=0.32$, so that the import-to-GDP ratio (1-n $\alpha$ in the home country) is equal to 0.16 in both countries. This is equivalent to the average import-to-GDP ratio observed in recent years in the U.S., and Japan, and in the Euro area (see for example World Bank (2015) and Coenen (2013)).

The risk premium in the UIP $\psi$ is set to 0.004, consistent with Bergin (2006), implying that a net external debt of 10 percent of output increases the domestic interest rate by four basis points relative to the foreign country. The Taylor rule coefficients are set as $\mu_{1}=0.79$ and $\mu_{2}=1.5$, following Clarida et al. (2000) and Taylor (1993).

Fiscal policy is calibrated in a way that the persistency of public investment and consumption shocks is 0.75 ( $\left.\rho^{i}=0.75, \mathrm{i}=\mathrm{I}, \mathrm{C}\right)$, consistently with the findings of Iwata (2013). The size of public spending shocks is 1 percent of initial GDP $\left(\varepsilon^{I}=\varepsilon^{C}=1\right)$.

We set the weight of public consumption to relative private consumption to $v_{1}=0.4$, as in Song et al. (2012)), who interpret this parameter as a measure of the efficiency in the provision of public goods.

We set the quarterly depreciation rate of public infrastructure to $\lambda=0.025$. This value is commonly used in models with public infrastructure (e.g. Bom and Lighhart (2014)).

The output elasticity of public infrastructure is a key parameter for the issue that we investigate in this paper. Given the quite wide range of estimates in the literature, we rely on the meta-analysis carried out by Bom and Lighhart (2013), which uses a sample of 578 estimates collected from 68 studies. Concluding that the short-run output elasticity of public 
capital supplied at the central government level of 0.083 . Accordingly, we set the benchmark value for output elasticity of public infrastructure at $\phi=0.083 .{ }^{4}$

Table 1. Parameterization of the Model

\begin{tabular}{|c|c|c|c|}
\hline Parameter & Baseline value & Description & Source \\
\hline$\beta$ & 0.995 & Discount factor & Iwata (2013) \\
\hline$n$ & 0.5 & $\begin{array}{l}\text { Relative size of the } \\
\text { domestic economy }\end{array}$ & \\
\hline$\theta$ & 11 & $\begin{array}{l}\text { Within-country } \\
\text { substitutability }\end{array}$ & Basu and Fernald (1997) \\
\hline$\rho$ & 1.5 & $\begin{array}{l}\text { Cross-country } \\
\text { substitutability }\end{array}$ & Dong (2012) \\
\hline$v$ & 0.7 & $\begin{array}{l}\text { Frisch elasticity of labor } \\
\text { supply }\end{array}$ & $\begin{array}{l}\text { Keane and Rogerson } \\
\text { (2012) and Chetty et al } \\
\text { (2013) }\end{array}$ \\
\hline$\gamma$ & 0.5 & Calvo parameter & Bils and Klenow (2004) \\
\hline$\alpha$ & 1.68 & Home bias parameter & $\begin{array}{l}\text { World Bank (2015) \& } \\
\text { Coenen (2013) }\end{array}$ \\
\hline$\alpha^{*}$ & 0.32 & Home bias parameter & $\begin{array}{l}\text { World Bank (2015) \& } \\
\text { Coenen (2013) }\end{array}$ \\
\hline$\psi$ & 0.004 & Risk premium in UIP & Bergin (2006) \\
\hline$\mu_{1}$ & 0.79 & Interest rate smoothing & Clarida et al. (2000) \\
\hline$\mu_{2}$ & 1.5 & $\begin{array}{l}\text { Coefficient for inflation in } \\
\text { the monetary policy rule }\end{array}$ & Taylor (1993) \\
\hline$\rho^{I}, \rho^{C}$ & 0.75 & $\begin{array}{l}\text { Persistency of public } \\
\text { spending shocks }\end{array}$ & Iwata (2013) \\
\hline$\varepsilon^{I}, \varepsilon^{C}$ & 1 & $\begin{array}{c}\text { Size of public spending } \\
\text { shocks }\end{array}$ & \\
\hline$v$ & 0.4 & $\begin{array}{l}\text { Weight of public } \\
\text { consumption }\end{array}$ & Song et al. (2012) \\
\hline$\lambda$ & 0.025 & $\begin{array}{l}\text { Depreciation rate of public } \\
\text { infrastructure }\end{array}$ & Bom and Lighhart (2014) \\
\hline$\phi$ & 0.083 & $\begin{array}{l}\text { Output elasticity of public } \\
\text { infrastructure }\end{array}$ & Bom and Lighhart (2013) \\
\hline
\end{tabular}

\footnotetext{
${ }^{4}$ We simulate the model using the algorithm developed by McCallum (2000) and Klein (2000)
} 


\section{Output and Welfare Multipliers of Public Spending}

In this section, we present our results on the output and welfare multipliers of fiscal stimulus. We derive both cumulative and net present value fiscal multipliers, where the cumulative multiplier (CM) is defined as the cumulative change of output (or of any other relevant variable) over the cumulative change of public spending as some horizon (see, for example, Gechert and Rannenberg (2014))

$$
C M=\frac{\Sigma_{h} d Y_{t+h}}{\sum_{h} d G_{t+h}^{i}}=\frac{\Sigma_{h} \hat{Y}_{t+h}}{\sum_{h} \hat{G}_{t+h}^{i}},
$$

while the net present value fiscal multiplier (NPVM) is the sum of output over a certain time horizon (in our analysis we use 2,000 periods) discounted at the steady state interest rate, and divided by government spending discounted in the same way (see Uhlig (2010)):

$$
N P V M=\frac{\sum_{s=t}^{h} \beta^{s-t} \hat{Y}_{s}}{\sum_{s=t}^{h} \beta^{s-t} \hat{G}_{s}^{i}}
$$

What differentiate our approach from most of the previous literature is that we calculate not only the net present value output multiplier but also the net present value welfare multiplier. In calculating the welfare multiplier, we follow Sims and Wolff (2013), who define it as the one period consumption equivalent change in the present discounted value of flow utility for a one unit (dollar) change in government spending. In order to do this, we first need to measure the welfare impact of fiscal policy as a percentage of initial consumption that the household is willing to pay for fiscal expansion to be as well off in the fiscal expansion case as in the initial equilibrium (see Schmitt-Grohe and Uribe (2007)).

Let $\left\{C_{s}^{W F E}, G_{s}^{W F E-C}, l_{s}^{W F E}(z)\right\}_{s=t}^{\infty}$ be the private and public consumption and labor supply paths without fiscal expansion (WFE). The associated net present value (NPV) of welfare is given by

$U_{N P V}^{W F E}=\sum_{s=t}^{\infty} \beta^{s-t}\left[\log \left(C_{s}^{W F E}\right)-\frac{\left(l_{s}^{W F E}(z)\right)^{1+1 / v}}{1+1 / v}+v \log G_{s}^{W F E, C}\right]$.

We can then define $\lambda_{N P V}$ as the NPV of the welfare impact of a fiscal expansion (FE) relative to case without fiscal expansion. It is measured as the fraction of initial private consumption - holding labor supply constant — that the household is willing to pay for fiscal 
expansion. In particular, if $U_{N P V}^{F E}$ denotes the net present value of welfare in the fiscal expansion case

$$
\begin{aligned}
& U_{N P V}^{F E}=\sum_{s=t}^{\infty} \beta^{s-t}\left[\log \left(\left(1+\lambda_{N P V}\right) C_{s}^{F E}\right)-\frac{\left(l_{s}^{F E}(z)\right)^{1+1 / v}}{1+1 / v}+v \log G_{s}^{F E, C}\right] \\
& U_{N P V}^{F E}=\frac{1}{1-\beta} \log \left(1+\lambda_{N P V}\right)+U_{N P V}^{W F E}
\end{aligned}
$$

we can solve for $\lambda_{N P V}$, and express the welfare impact of a fiscal expansion as the percentage (rather than as a fraction) of consumption, as follows

$$
\lambda_{N P V}=100 \times\left[\exp (1-\beta)\left(U_{N P V}^{F E}-U_{N P V}^{W F E}\right)-1\right]
$$

Taking a first-order Taylor expansion of the utility function (1), we have

$$
d U_{N P V}=U_{N P V}^{F E}-U_{0}=\sum_{s=t}^{\infty} \beta^{s-t} d U_{s}^{F E}=\sum_{s=t}^{\infty} \beta^{s-t}\left(\hat{C}_{s}^{F E}-\left(l_{0}(z)\right)^{1+1 / v} \hat{l}_{s}^{W E}(z)+v \hat{G}_{s}^{F E, C}\right.
$$

Welfare without fiscal expansion would be the same as in the initial steady state. Substituting (14) into (13) we can derive the NPV of the welfare impact of fiscal expansion as the percentage of initial consumption

$$
\lambda_{N P V}=100 \times\left[\exp (1-\beta)\left(\sum_{s=t}^{\infty} \beta^{s-t}\left(\hat{C}_{s}^{F E}-\left(l_{0}(z)\right)^{1+1 / v} \hat{l}_{s}^{F E}(z)+v \hat{G}_{s}^{F E, C}\right]\right)-1\right]
$$

Finally, to calculate the (domestic) welfare multiplier $\left(M_{U}\right)$ of a fiscal expansion we divide (15) by public spending discounted the same way:

$$
M_{U}=\frac{100 \times\left[\exp (1-\beta)\left(\sum_{s=t}^{\infty} \beta^{s-t}\left(\hat{C}_{s}^{F E}-\left(l_{0}(z)\right)^{1+1 / v} \hat{l}_{s}^{F E}(z)+v \hat{G}_{s}^{F E, C}\right]\right)-1\right]}{\sum_{s=t}^{\infty} \beta^{s-t} \hat{G}_{s}^{i}}
$$

As we have already mentioned above, the welfare multiplier is the consumption equivalent change in welfare for one dollar change government spending. For example, if the welfare multiplier is 0.5 , this means that a one dollar increase in public spending yields the welfare improvement that corresponds 0.5 dollars increase in domestic private consumption. 
Our open economy framework enables the analysis of the welfare multiplier for the world economy, while the existing models have studied welfare multipliers in closed economies. The welfare multiplier for the world economy is the sum of the consumption equivalent changes in welfare for one dollar change in domestic government spending:

$$
M_{U}^{W}=\frac{\lambda_{N P V}+\lambda_{N P V}^{*}}{\sum_{s=t}^{\infty} \beta^{s-t} \hat{G}_{s}^{i}} .
$$

In figure 1 we plot the value of fiscal expansion (not the welfare multiplier), measured by the percentage of initial consumption, that the household in willing to play for the fiscal expansion in period $t$ :

$\left.\lambda_{t}=100 \times\left[\exp (1-\beta)\left(\hat{C}_{s}^{F E}-\left(l_{0}(z)\right)^{1+1 / v} \hat{l}_{s}^{F E}(z)+v \hat{G}_{s}^{F E, C}\right]\right)-1\right]$.

\section{A. Public Consumption}

Figure 1 shows the impulse responses of domestic and foreign variables to a one percent increase in domestic public spending. The solid (dashed) lines show the effects of a public consumption (investment) shock. Generally speaking, variables are expressed in percent deviations from the initial steady state. However, the change in the trade balance, which initial value is zero, and the value of trade liberalization are expressed as deviations from initial consumption, and inflation is expressed in percentage points in annual terms.

A government consumption spending shock increases domestic output. This is due to both to the increase in aggregate demand and to the wealth effect that, with endogenous labor supply, pushes domestic agents to work more when domestic taxes are increased.

Table 2 shows that the cumulative output multipliers of public consumption are in the 0.4-0.5 range, which is consistent with the empirical evidence provided by Gechert and Rannenberg (2014) in a meta-analysis of fiscal multipliers based 98 empirical studies with more than 1800 observations. 
Figure 1. Effects of Fiscal Expansion.
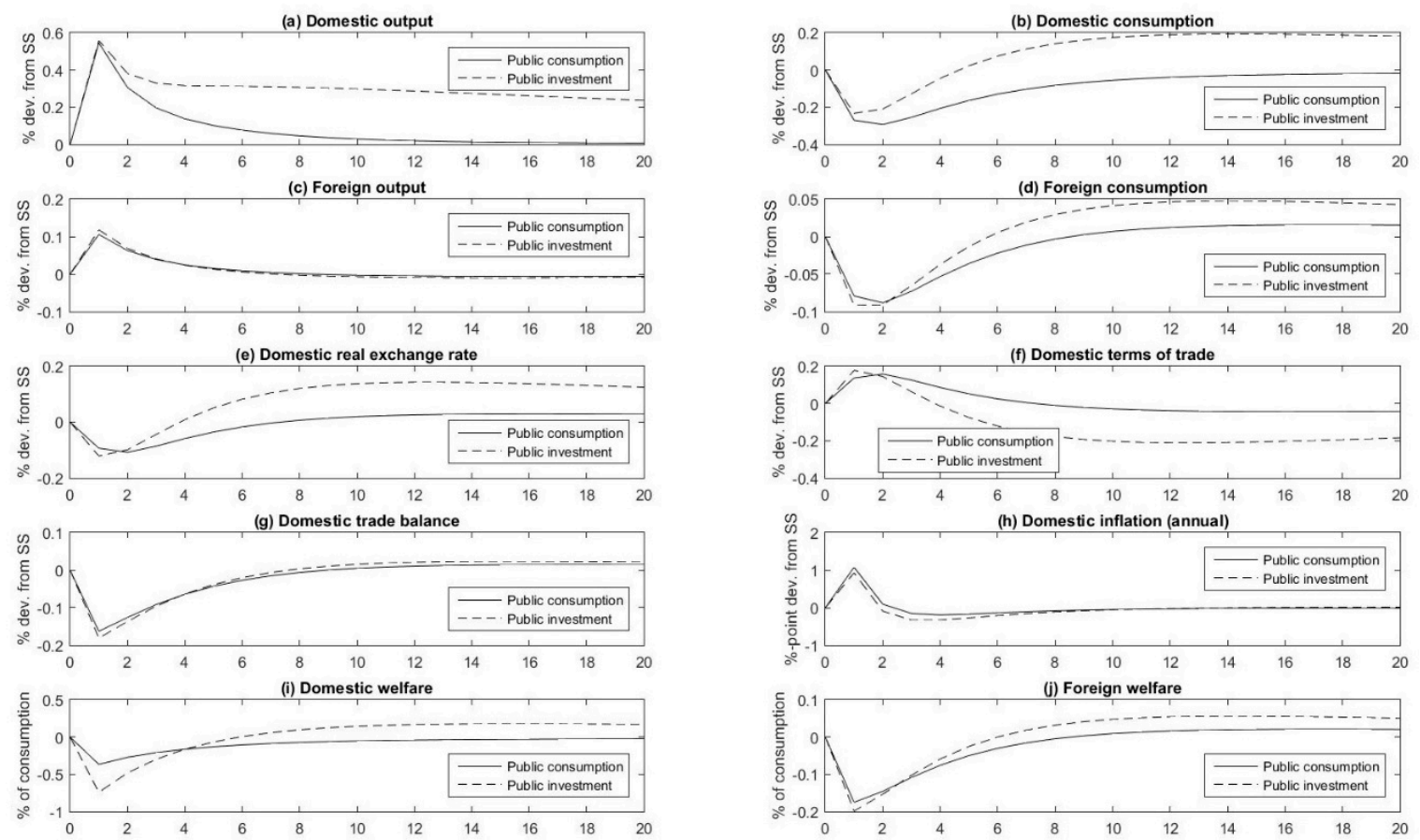

The domestic trade balance initially deteriorates, due to the import component of the increased government spending. In the medium term, however, the fall in domestic consumption due to higher taxes, together with the improvement in the domestic terms of trade (defined as the relative producer price of domestic exports in terms of imports), imply an improvement in the domestic trade balance. Such hump-shaped behavior of the trade balance is consistent with the empirical evidence provided by Iwata (2013).

The dynamics of other variables, including a short-lived increase in inflation due to the demand shock, and an appreciation of the domestic real exchange rate followed by a depreciation, are also consistent with Iwata (2013).

Turning to spillover effects, we observe an increase in foreign output, due to both the increased demand in foreign goods stemming from the domestic fiscal shock and the shortterm appreciation of the domestic exchange rate in the short term. However, given the substantial level of home bias in government spending, this positive spillover effect is not very large in quantitative terms.

Let's now turn our attention to welfare effects, which are the main focus of our paper. Following a domestic government spending shock, there are two contrasting effects on domestic welfare. On one hand, the increase in labor supply and the fall in private 
consumption due to higher taxes and the terms of trade imply a fall in domestic welfare. On the other hand, public consumption yields utility, so an increase in public consumption increases welfare

As it can be seen from Figure 1, in the case of public consumption the first (negative) welfare effects dominate, because the weight of public consumption in private utility is small. As shown in Table 2 below, the welfare multiplier for domestic households is -0.3 , meaning that they are willing to pay 0.3 dollars to avoid one dollar rise in public consumption.

In comparing our results with the previous literature, it is interesting to notice that Sims and Wolff (2013), find a huge variability in the welfare multiplier, which, depending on the steady-state level of government spending, ranges between -8.6 and 35, while their output multiplier is 1.2. While in our benchmark parameterization we get a negative welfare multiplier for a public consumption shock, our model could also yield a positive output multiplier if government spending was set lower than would be the case if the government picked spending to maximize welfare. For instance, if we set the weight of public consumption $v=1$ (compared to 0.4 in the benchmark parameterization), our welfare multiplier becomes positive, although just above zero. If $v=1.5$, the welfare multiplier would be 0.25 . This implies than even in the (rather extreme) case in which the weight of public consumption is larger than the weight of private consumption in the utility function, our range for the welfare multiplier is much smaller (and, in our view, more plausible) than in Sims and Wolff (2013).

Our results are consistent with Rendhal (2015), who finds that for a fiscal expansion of long duration the welfare multiplier is 0.65 , while for a more temporary fiscal expansion it is smaller, and can turn negative. In particular if the duration of the fiscal expansion is $0-20 \%$ that of the crisis that drives the economy into a liquidity trap, the welfare multiplier is in the range of -0.4 to -0.2 , which is very close to what we find in our benchmark case.

The welfare spillover effect on the foreign economy, measured by (15), is positive. This reflects the fact that the improvement in the foreign terms of trade implies that foreign consumption rises by more than foreign output, which brings about a welfare improvement because it means that foreign agents can increase their consumption with a proportionately lower increase in labor supply. The positive spillover effect implies that the world welfare multiplier is less negative $(-0.28)$ than that of the domestic economy $(-0.30)$. 
Table 2. Output and Welfare Multipliers. $\mathrm{CM}=$ cumulative output multiplier, $\mathrm{PRs}=$ periods.

\begin{tabular}{|c|c|c|c|c|c|c|c|c|}
\hline & $\mathrm{CM}$, & $\mathrm{CM}$, & $\mathrm{CM}$, & $\mathrm{CM}, 16$ & $\mathrm{CM}$, & NPV of & Welfare & World \\
& $\begin{array}{c}4 \\
\text { oRs }\end{array}$ & $\begin{array}{c}8 \\
\text { PRs }\end{array}$ & $\begin{array}{c}12 \\
\text { PRs }\end{array}$ & $\begin{array}{c}\text { PRs } \\
20 \\
\text { PRs }\end{array}$ & $\begin{array}{c}\text { output } \\
\text { multiplier }\end{array}$ & multiplier & $\begin{array}{c}\text { welfare } \\
\text { multiplier }\end{array}$ \\
\hline Consumption & 0.44 & 0.41 & 0.41 & 0.41 & 0.42 & 0.46 & -0.30 & -0.28 \\
\hline Investment & 0.58 & 0.79 & 1.0 & 1.3 & 1.5 & 3.2 & 0.77 & 0.91 \\
\hline
\end{tabular}

\section{B. Public Infrastructure Investment}

In this section, we focus on the effects of an increase in public infrastructure investment, including welfare effects. The latter is the main innovation of our analysis, given that papers which focus on the welfare effects of an infrastructure push are scarce in the literature. Below, we discuss how the macroeconomic effects of our public infrastructure investment increase, especially the output multipliers, are very well in line with the existing empirical evidence. This lends credibility to our welfare analysis, because it means that our study looks at the welfare impact of this policy in a reasonably realistic framework.

In the case of a public infrastructure investment shock we have both a temporary demand effect and a supply-side effect, because the productive capacity of firms increased with a higher infrastructure stock. The second effect was missing in the previous case of a public consumption shock. Consequently, an infrastructure investment push increases medium-term output (Figure 1(a)), relative to the public consumption case. As it can be seen in Table 2, the cumulative multiplier increases with time, as a higher infrastructure stock expands productive capacity. The time pattern of the output response is consistent with the empirical evidence of Iwata (2013), who shows that the short-term effect of public investment is higher than the medium-term effect.

Table 3. Output Multipliers. $\mathrm{CM}=$ cumulative output multiplier, $\mathrm{PRs}=$ periods.

\begin{tabular}{|c|c|c|c|c|c|}
\hline & CM, 4 PRs & CM, 8 PRs & CM, 12 PRs & CM,16 PRs & CM, 20 PRs \\
\hline IMF (2014) & 0.5 & 0.7 & 1 & 1.3 & 1.5 \\
\hline Our model & 0.6 & 0.8 & 1 & 1.3 & 1.5 \\
\hline
\end{tabular}

Table 3 shows cumulative output multipliers by IMF's (2014) empirical study and our findings. Our multipliers in the first five years after the shock are almost identical to the findings of IMF (2014). Our results are also in line with the meta-analysis carried out by Gechert and Rannenberg's (2014), who find that the cumulative fiscal multiplier of public investment is 1.4 . 
Coenen et al. (2012) use seven structural DSGE models, all used heavily by policymaking institutions, to study the output multipliers of fiscal policy. A result: the average first-year multiplier for public investment spending is 1.5 , only slightly higher than the multiplier for consumption spending. In our model, the output multiplier of public investment is much smaller (0.6) and much more in line with the empirical evidence of IMF (2014), according to which the first-year output multiplier is only 0.5 .

As Table 2 shows, the NPV of the output multiplier, at 3.2, is much higher than the cumulative multipliers. This result is mainly due to the fact that, after four years, public investment spending has in essence returned to zero, but output remains high due to the increase in the productive capacity generated by higher public infrastructure. While very few papers have studied the long-term effects of public investment, our results point to a significantly stronger output effect of public investment in the long run compared to the existing literature. In the theoretical model developed by Bom and Lighhart (2014), for example, the long-run output multiplier of a permanent increase in public investment is 2.3 , while Leduc and Wilson (2013) estimate that output returns back to its pre-shock level after ten years. This might suggest that our model could be overestimating the long-term benefits of public investment. On the other end, out results are consistent with the conclusion by Bom and Lighhart (2013) that public capital is more productive in the long term than in the short term.

As Figure 1 shows, consumption falls in the short term. This result is determined by the increase in the taxation needed to finance higher public investment. The public investment shock also temporarily increases the terms of trade in the short term, which tends to increase private consumption, but the tax effect dominates, so that consumption falls in the short term.

The trade balance effect is quantitatively in line with those observed in the case of a consumption shock. Even though domestic private consumption goes down in the short term for the reason discussed above, we observe a deterioration of the overall domestic trade balance in the short term, due to higher public spending for investment. In the medium, term the terms of trade dynamics is reversed. This is consistent with the empirical evidence of Iwata (2013), who finds that the trade deficit first worsens and then improves following a public investment shock.

As in the empirical analysis of Iwata (2013), a public investment shock increases private consumption and brings about an initial appreciation of the real exchange rate, followed by a depreciation, while the short term interest rate (not shown in our graph) increases due to the reaction function of the central bank following the increase in inflation. 
Overall, the macroeconomic effects of our public infrastructure investment shock are in line with the empirical evidence. This lends credibility to our welfare results, which are the main innovation of this paper, to which we now turn.

As it can be seen from Table 2, our model points to substantial gains from a public infrastructure investment shock. The welfare multiplier of a public infrastructure investment is 0.77 , meaning that households would be willing to pay 0.77 dollars for a one dollar increase in public infrastructure investment. The main intuition for this result is that the gains in productivity linked to enhanced public infrastructures imply an increase in consumption without an increase in labor supply, which improves welfare.

Figure 1(j) shows that the welfare spillover effect is positive after some time. The improvement in the foreign terms of trade implies that foreign consumption rises by more than the foreign labor supply and output. The positive welfare spillover implies that the world welfare multiplier is larger (0.91) than the domestic welfare multiplier (0.77). Domestic and foreign households combined would be willing to pay 0.91 dollars for a one dollar increase in domestic public infrastructure investment.

To the best of our knowledge, ours is the first paper which analyzes the welfare multiplier of public investment spending. Bom and Ligthart (2014) study the welfare effects of public investment and show that a permanent increase in public investment raises welfare in the long term if the output elasticity of public capital exceeds the public investment-to-GDP ratio (which in OECD countries averages 3 percent). Since Bom and Ligthart (2014) show that the welfare results are sensitive to the output elasticity of public infrastructure, we have conducted some sensitivity analysis to see how our results depend on this parameter.

The results of our sensitivity analysis are reported in Table 4. As it can be seen, in our model the welfare multiplier is close to zero $(-0.042)$, when the output elasticity of public infrastructure is 0.03. IMF (2014) estimates that in case of low efficiency of public infrastructure the output multipliers are 0.6 and 0.7 after 4 and 5 years. Matching these numbers implies setting the output elasticity of public infrastructure to 0.02 . In this case, the welfare multiplier is -0.19 , compared to 0.77 in our benchmark case. Our findings are in line with those of Bom and Ligthart (2014), who find that the welfare effects of public infrastructure investment turn to negative when the output elasticity of public capital is smaller than three percent.

What about the case of high efficiency in public investment? According to IMF (2014), in case of high efficiency of public infrastructure the output multipliers are 2.1 and 2.3 after 4 and 5 years. We can roughly match those numbers by setting the output elasticity of public infrastructure to 0.131, which is also the estimate provided by Ligthart and Bom (2014) 
estimate for the short-term output elasticity of core public infrastructure. As shown in Table Table 4, the welfare multiplier in this case reaches the very high values of 1.5. If public investment is chosen widely, they lead to high welfare gains.

The policy implications of our analysis are clear: improving the productivity of public spending is key to fully reaping the benefits of an infrastructure spending push. For countries with a low elasticity of public infrastructure an increase in public investment is not desirable from a welfare point of view, because it implies a negative welfare multiplier. On the other hand, countries in which public spending is very efficient can realize very high utility gains from more spending on infrastructures.

Welfare multipliers may be sensitive to the value of within-country substitutability, because it governs the level of initial output/employment. The lower it is, the more an increase in employment output and private consumption (of given size) increases welfare. If withincountry substitutability is set to 6 (21), implying a 20 (5) percent markup over marginal costs, the domestic welfare multiplier of public infrastructure investment increases (drops) to $0.79(0.76)$, when the output elasticity of public infrastructure is 0.083 . Hence, welfare multipliers are not sensitive to changes in within-country substitutability. ${ }^{5}$

In summary, our results suggest that if public infrastructure is sufficiently productive, public investment may be a very effective way to stimulate the economy not only from the output point of view, but also from the point of view of welfare.

Table 4. Productivity of Public Infrastructure and Multipliers

\begin{tabular}{|c|c|c|c|c|c|}
\hline $\begin{array}{c}\text { Output elasticity } \\
\text { of public capital }\end{array}$ & $\begin{array}{c}\text { CM,16 } \\
\text { periods }\end{array}$ & $\begin{array}{c}\text { CM, 20 } \\
\text { periods }\end{array}$ & $\begin{array}{c}\text { NPV of output } \\
\text { multiplier }\end{array}$ & $\begin{array}{c}\text { Welfare } \\
\text { multiplier }\end{array}$ & $\begin{array}{c}\text { World welfare } \\
\text { multiplier }\end{array}$ \\
\hline$\phi=0.02$ & 0.62 & 0.68 & 1.1 & -0.19 & -0.14 \\
\hline$\phi=0.03$ & 0.73 & 0.82 & 1.5 & -0.042 & 0.021 \\
\hline$\phi=0.083$ & 1.3 & 1.5 & 3.2 & 0.77 & 0.91 \\
\hline$\phi=0.131$ & 1.8 & 2.2 & 4.8 & 1.5 & 1.7 \\
\hline
\end{tabular}

\section{CONCLUSiOnS}

This paper is the first to analyze the welfare multiplier of public infrastructure investment. The welfare multiplier of public investment, under a plausible parameterization, is quite sizable. The fact that the output response is consistent with empirical evidence lends

\footnotetext{
${ }^{5}$ In addition, welfare multipliers are not responsive to changes in the Frisch elasticity of labor supply.
} 
credibility to our welfare analysis. For countries with a high elasticity of public infrastructure an increase in public investment is desirable from a welfare point of view, because it implies a positive welfare multiplier. In our model, the welfare multiplier is positive, when the output elasticity of public infrastructure is slightly higher than three percent, while the meta-analysis by Bom and Lighhart (2013) shows that it eight percent in practice. This suggests that the welfare multiplier of public infrastructure investment is likely to be positive.

However, improving the productivity of public spending is the key to fully reaping the benefits of an infrastructure spending push. IMF (2015) finds that improvements in public investment management can significantly enhance the productivity of public investment and argues that governments should strengthen institutions that are responsible for the planning, allocation, and implementation of public investments. Good public investment management is needed to ensure a positive welfare multiplier of public investment.

IMF (2014) shows that in a debt-financed increase in public infrastructure investment reduces the public debt-to-GDP ratio. The main policy implication of our analysis is that the time seems right for a global infrastructure push: it would not only increase output and reduce public debt-to-GDP ratio - as shown by earlier studies - but also yield quite sizable welfare benefits. 


\section{REFERENCES}

Basu, P. and R. Kollman 2013, Productive government purchases and the real exchange rate. The Manchester School 81, 461-469.

Basu, S. and J. G. Fernald, 1997. Returns to scale in U.S. production: Estimates and implications. Journal of Political Economy 105, 249-283.

Bergin, P. R, 2006. How well can the new open economy macroeconomics explain the exchange rate and current account? Journal of International Money and Finance 25, 675-701.

Bils, M. and P. Klenow 2004. Some evidence on the importance of sticky prices. Journal of Political Economy 112, 947-985.

Bom, P.R.D and J. E. Ligthart R, 2013. What have we learned from three decades of research on the productivity of public capital. Journal of Economic Surveys 28, 889-916.

Bom, P.R.D and J. E. Ligthart, 2014. Public infrastructure investment, output dynamics, and balanced budget fiscal rules. Journal of Economic Dynamics \& Control 40, 334-354.

Calvo, G. A., 1983. Staggered prices in a utility maximizing framework. Journal of Monetary Economics 12, 383-398.

Clarida, Richard, Jordi Galí, and Mark Gertler, 2000. Monetary policy rules and macroeconomic stability: Evidence and some theory. Quarterly Journal of Economics, Vol. 115, No. 1, pp. 147-180.

Chetty, R., A. Guren, D. Manoli and A. Weber, 2013. Does indivisible labor explain the difference between micro and macro elasticities? A meta-analysis of extensive margin elasticities. NBER Macroeconomics Annual 2012 27, 1-56.

Coenen, G., C. J. Erceg, C. Freedman, D. Furceri, M. Kumhof, R. Lalonde, D. Laxton, J. Lindé, A. Mourougane, D. Muir, S. Mursula, C. de Resende, J. Roberts, W. Roeger, S. Snudden, M. Trabandt, and J. In't Veld 2012. Effects of fiscal stimulus in structural models. American Economic Journal: Macroeconomics 4, 22-68.

Coenen, G., Straub, R. and M.Trabandt 2013. Gauging the effects of fiscal stimulus packages in the euro area. Journal of Economic Dynamics \& Control 37, 367-386. 
Dong, W. 2012. The role of expenditure switching in the global imbalance adjustment. Journal of International Economics 86, 237-251.

Gechert, S. and A. Rannenberg 2014. Are fiscal multipliers regime-dependent? A meta regression analysis, IMK Working Paper 139.

IMF 2014. World economic outlook: Legacies, clouds, uncertainties. IMF, Washington, DC.

IIMF 2015. Making public investment more efficient. IMF, Washington, DC.

Iwata, Y, 2013. Two fiscal policy puzzles revisited: New evidence and an explanation. Journal of International Money and Finance 33, 188-207.

Keane, M. and R. Rogersson, 2012. Micro and macro labor supply elasticities: A reassessment of conventional wisdom. Journal of Economic Literature 50, 464-476.

Klein, P., 2000. Using the generalized Schur form to solve a multivariate linear rational expectations model. Journal of Economic Dynamics and Control 24, 1405-1223.

Leduc, S. and D. Wilson 2013, Roads to prosperity or bridges to nowhere? Theory and evidence on the impact of public infrastructure investment. NBER Macroeconomics Annual 27, 89-142.

Mankiw, G. and M. Weinzierl, An exploration of optimal stabilization policy. Brookings Papers on Economic Activity 42, 209-272.

McCallum, B., 2001, Software for RE analysis. Computer software available at http://wpweb2.tepper.cmu.edu/faculty/mccallum/research.html

Obstfeld, M. and K. Rogoff 1995. The intertemporal approach to the current account. In G. Grossman and K. Rogoff (eds.) Handbook of International Economics. North-Holland Publishing Company, Amsterdam.

Rendahl, P. 2015. Fiscal policy in an unemployment crisis. Mimeo, University of Cambridge.

Schmitt-Grohe, S. and M. Uribe, 2003. Closing small open economy models. Journal of International Economics 61, 163-185.

Schmitt-Grohe, S. and M. Uribe, 2007. Optimal simple and implementable monetary and fiscal rules. Journal of Monetary Economics 54, 1702-1725. 
Sims, E. and J. Wolff, 2014. The output and welfare effects of government spending shocks over the business cycle. NBER Working Paper No 19749.

Song, Z., K. Storesletten and F. Zilibotti 2012. Rotten parents and disciplined children: A politico-economic theory of public expenditure and debt. Econometrica 80, 27852803.

Taylor, J. B. 1993. Discretion versus policy rules in practice. Carnegie-Rochester Conference Series on Public Policy 39, 195-214.

Uhlig, H., 2010. Some fiscal calculus. American Economic Review 100, 30-34.

World Bank, 2015. Data available online at http://data.worldbank.org/ (accessed 12.3.2015). 